\title{
SARS-CoV-2 spike protein induces inflammation via TLR2-dependent activation of the NF-KB pathway
}

Shahanshah Khan ${ }^{1}$, Mahnoush S. Shafiei ${ }^{1}$, Christopher Longoria ${ }^{2}$, John Schoggins ${ }^{3}$, Rashmin C.

Savani², and Hasan Zaki ${ }^{*}$

${ }^{1}$ Department of Pathology, ${ }^{2}$ Department of Pediatrics, ${ }^{3}$ Department of Microbiology

UT Southwestern Medical Center, Dallas, TX 75390

\section{*Corresponding Author:}

Hasan Zaki, PhD

Department of Pathology

UT Southwestern Medical Center

5323 Harry Hines Blvd

Dallas, TX 75390

Tel: 214-648-5196; Fax: 214-648-1102

E-mail: Hasan.Zaki@utsouthwestern.edu

Key Words: COVID-19, SARS-CoV-2, Spike protein, Cytokine storm, TLR2, Inflammation 


\begin{abstract}
Pathogenesis of COVID-19 is associated with a hyperinflammatory response; however, the precise mechanism of SARS-CoV-2-induced inflammation is poorly understood. Here we investigated direct inflammatory functions of major structural proteins of SARS-CoV-2. We observed that spike (S) protein potently induces inflammatory cytokines and chemokines including IL-6, IL-1 $\beta$, TNF $\alpha$, CXCL1, CXCL2, and CCL2, but not IFNs in human and mouse macrophages. No such inflammatory response was observed in response to membrane (M), envelope (E), and neucleocapsid $(\mathrm{N})$ proteins. When stimulated with extracellular S protein, human lung epithelial cells A549 also produce inflammatory cytokines and chemokines. Interestingly, epithelial cells expressing S protein intracellularly are non-inflammatory, but elicit an inflammatory response in macrophages when co-cultured. Biochemical studies revealed that S protein triggers inflammation via activation of the NF- $\kappa \mathrm{B}$ pathway in a MyD88-dependent manner. Further, such an activation of the NF- $\mathrm{KB}$ pathway is abrogated in Tlr2-deficient macrophages. Consistently, administration of S protein induces IL-6, TNF- $\alpha$, and IL-1 $\beta$ in wild-type, but not Tlr2-deficient mice. Together these data reveal a mechanism for the cytokine storm during SARS-CoV-2 infection and suggest that TLR2 could be a potential therapeutic target for COVID-19.
\end{abstract}




\section{INTRODUCTION}

Coronavirus induced disease (COVID) 19, caused by severe acute respiratory syndrome coronavirus 2 (SARS-CoV-2), has emerged as a major public health crisis since December 2019 (1-3). SARS-CoV-2 is a positive sense single stranded RNA virus. Like other coronaviruses, such as SARS (retrospectively named SARS-CoV-1) and Middle Eastern respiratory syndrome (MERS)-CoV, SARS-CoV-2 primarily causes infection in the respiratory tract, leading to either asymptomatic infection or a range of symptoms including cough, fever, pneumonia, respiratory failure, along with other complications like diarrhea and multi-organ failure (4-7). In the absence of effective therapies, COVID-19 has caused 1.8 million deaths worldwide by the end of 2020 . Although our knowledge is still evolving, immunopathology caused by cytokine storm plays a decisive role in COVID-19 pathogenesis $(4,5,8)$.

SARS-CoV-2 infects human cells through its Spike (S) protein, which binds to the receptor angiotensin converting enzyme 2 (ACE2), expressed on alveolar epithelial cells, allowing endocytosis of the viral particle $(1,9)$. Following endocytosis, the viral genome is replicated using both viral and host machineries, leading to the death of virally infected cells (10). The pathology of SARS-CoV-2 infected lung is further worsened with inflammatory responses of innate immune cells such as macrophages, monocytes, and neutrophils, which are activated by viral components and products of apoptotic and necrotic cells (3). While innate immune response is essential for anti-viral host defense, excessive inflammatory cytokines and chemokines are cytotoxic for respiratory epithelial cells and vascular endothelial cells (11). Indeed, clinical manifestation of COVID-19 is marked by higher levels of IL-2, IL-6, IL-8, TNF $\alpha$, IFN $\gamma$, MCP1, MIP1 $\alpha$, IP-10, and GMCSF in patient's blood $(3,12,13)$. Disease severity and death of COVID-19 patients have 
been correlated to the elevated levels of IL-6 and TNF $\alpha(3,14)$. However, our understanding of the precise mechanism of induction of proinflammatory cytokines and chemokines during SARSCoV-2 infection is very limited.

The innate immune inflammatory response is initiated with the recognition of pathogen-associated molecular patterns (PAMPs) by pattern recognition receptors (PRRs), such as Toll-like receptors (TLRs), NOD-like receptors (NLRs), and RIG-I like receptors (RLRs). Activated PRRs involve multiple signaling adapters to activate transcription factors, such as NF- $\mathrm{B}$, AP1, and IRF3, which regulate the expression of genes involved in immunity and inflammation. RNA sensing receptors such as TLR7, RIG-I, and MDA5 play a central role in anti-viral immunity by inducing type I interferons (IFN $\alpha$ and IFN $\beta$ ) via IRF3 and NF- $\kappa B(15-19)$. Although the relative contribution of RNA sensing pathways in SARS-CoV-2-mediated immunopathology is yet to be explored, previous studies reported that macrophages and dendritic cells infected with SARS-CoV-1 produce proinflammatory cytokines and chemokines, but not type I interferons (20, 21). Consistently, inflammatory responses in severe COVID-19 patients are characterized by high levels of proinflammatory cytokines, but poor type I interferon response $(8,14)$. Beyond these phenotypic observations, the precise mechanism of the hyperinflammatory response during SARS-CoV-2 infection is poorly understood.

SARS-CoV-2 is an enveloped virus consisting of four major structural proteins - S, nucleocapsid $(\mathrm{N})$, membrane (M), and envelop (E) (22). S protein binds to the receptor binding domain of ACE2 through its S1 subunit allowing proteasomal cleavage of S protein and fusion of the S2 subunit with the host cell membrane $(9,10,23-25)$. Thus, SARS-CoV-2 structural proteins are likely to be 
exposed to PRRs located on the cell membrane, endosome, and cytosol of the infected cell. However, our knowledge on the role of SARS-CoV-2 structural proteins in the innate immune response is very limited. Here, we investigated inflammatory properties of S, M, N and E proteins and revealed that $\mathrm{S}$ protein, but not $\mathrm{M}, \mathrm{N}$, and $\mathrm{E}$ proteins, is a potent viral PAMP, which stimulates macrophages, monocytes, and lung epithelial cells. We demonstrated that $\mathrm{S}$ protein is sensed by TLR2, leading to the activation of the NF- $\kappa \mathrm{B}$ pathway and induction of inflammatory cytokines and chemokines. This study provides critical insight into molecular mechanism that may contribute to cytokine storm during SARS-CoV-2 infection.

\section{RESULTS}

SARS-CoV-2 S protein induces inflammatory cytokines and chemokines in macrophages and monocytes

Macrophages play a central role in hyperinflammatory response during SARS-CoV-2 infection(26). To understand whether SARS-CoV-2 structural proteins can activate macrophages and monocytes, we stimulated human monocytic cell THP1-derived macrophages with recombinant $\mathrm{S} 1, \mathrm{~S} 2, \mathrm{M}, \mathrm{N}$ and $\mathrm{E}$ proteins. Interestingly, both $\mathrm{S} 1$ and $\mathrm{S} 2$ proteins induced proinflammatory cytokines IL-6, TNF $\alpha$, and IL-1 $\beta$, with S2 being more potent, as measured by real-time PCR and ELISA (Figure 1A and Figure S1A). Chemokines produced by macrophages and monocytes recruit $\mathrm{T}$ cell and other immune cells in the inflamed tissue, aggravating inflammatory damage $(4,26)$. Both S1 and S2 subunits of S protein induced chemokines including CXCL1, CXCL2, and CCL2 in THP1 cells (Figure 1A). Three other structural proteins - M, N and E - did not induce any cytokines and chemokines (Figure 1A). Interferons are critical for adaptive immune response and anti-viral immunity (16). However, THP1 cells did not express either type 
I (IFN $\alpha$ and IFN $\beta$ ) and Type II (IFN $\gamma$ ) interferons in response to any of the SARS-CoV-2 structural proteins (Figure 1A). Notably, THP1 cells are not defective in producing interferons when activated by PolyI:C, a ligand for TLR3 (Figure S1B).

The expression of cytokines and chemokines in response to S protein was dose dependent (Figure 1B). Similarly, S protein-induced inflammatory response was time dependent, with highest being at $8 \mathrm{~h}$ post stimulation (Figure 1C). Notably, heat-denatured S2 protein failed to stimulate THP-1 cells, confirming the specificity of S protein and requirement of its native structural configuration in inducing inflammatory response (Figure S1C). To obtain a direct evidence that S protein can induce inflammatory mediators in human immune cells, we stimulated human peripheral blood mononuclear cells (hPBMC) with S2. There was robust induction of IL1b, IL6, TNFa, CXCL1, and CXCL2 in $\mathrm{hPBMC}$ at $4 \mathrm{~h}$ post stimulation (Figure 1D).

SARS-CoV-2 do not infect mouse cells since S protein cannot bind mouse ACE2 receptor. To understand whether recognition of S protein by ACE2 is required for induction of inflammatory molecules, we stimulated mouse bone marrow-derived macrophages (mBMDMs) with S1 and S2. Interestingly, both S1 and S2 proteins stimulated mBMDMs, expressing Il6, Il1b, Tnfa, Cxcl1 and Cxcl2 (Figure S2A). Similar to THP1 cells, mBMDMs did not produce type I and Type II interferons in response to S protein (Figure S2A). Murine macrophage cell line RAW264.7 cells also responded to S2 protein, producing Il6, Tnfa, and Illb (Figure S2B). Taken together, SARSCoV-2 S protein potentially induces proinflammatory cytokines and chemokines in macrophages and monocytes. 


\section{Epithelial cells produce inflammatory mediators in response to SARS-CoV-2 S protein}

SARS-CoV-2 primarily infect epithelial cells of the lung, kidney, intestine, and vascular endothelial cells $(9,27-29)$. However, it is poorly understood whether SARS-CoV-2-infected epithelial cells produce proinflammatory cytokines and contribute to cytokine storm of COVID19 patients. To address this concern, we stimulated human lung cancer epithelial cells A549 and human embryonic kidney epithelial cells HEK293T cells with S1 or S2 proteins. However, there was no induction of IL6,ILIb, TNFa, CXCL1, and CXCL2 in either of the epithelial cells in response to $\mathrm{S}$ proteins at $4 \mathrm{~h}$ post stimulation (Figure S3). Given that epithelial cells are weaker than innate immune cells in expressing inflammatory mediators, we wondered whether the expression of inflammatory molecules in A549 cells is delayed. We, therefore, measured cytokines and chemokines in A549 cells following stimulation with S1 and S2 at 12 and 24h. Interestingly, both S1 and S2 proteins induced proinflammatory cytokines IL6, IL $1 b, T N F a$, and chemokines CXCL1 and CXCL2, with highest being at $24 \mathrm{~h}$ post stimulation (Figure 2A). IFN $\gamma$, but not Type I interferons, was poorly induced by S2 protein in A549 cells (Figure 2A).

We next verified whether cytosolic S protein can stimulate inflammatory response in epithelial cells. Therefore, we transfected HEK293T and A549 cells with plasmids expressing flag-tagged S protein or green florescent protein (GFP). The expression of S protein in HEK293T and A549 cells was confirmed by Western blotting and ELISA (Figure S4A-C). However, cytosolic expression of S protein did not induce any cytokines and chemokines in HEK293T cells or A549 cells (Figure 2B and 2C). These data suggest that intracellular $S$ protein does not induce inflammatory responses in epithelial cells. 


\section{Epithelial cells expressing $S$ protein trigger inflammation in macrophages}

Since airway and other epithelial cells are primary target of SARS-CoV-2, we wondered whether virally infected epithelial cells trigger inflammatory response in macrophages and monocytes in a paracrine manner. To address this concern, we collected culture supernatant of HEK293T-S cells or A549-S cells and added (30\% V/V) into the culture medium of THP1 cells (Figure 3A). However, culture supernatants of S protein-expressed epithelial cells failed to induce cytokines IL-6, IL-1 $\beta$, and TNF $\alpha$ in THP1 cells (Figure 3B and 3C). In fact, S protein was not detectable in the culture supernatant of HEK293T and A549 cells expressing S protein (Figure S4C). Flow cytometric analysis suggested that $\mathrm{S}$ protein is primarily located in the cytoplasm, not on the cell surface (Figure S4D).

We then sought to examine whether innate immune cells become activated when they physically interact with S protein-expressed epithelial cells. Hence, we co-cultured HEK293T-S or A549-S cells with THP1 cells at 1:2 ratio (Figure 3D). Impressively, inflammatory cytokines were appreciably induced in co-cultured cells (Figure 3E-F). We confirmed protein levels of IL-6, IL$1 \beta$, and $\mathrm{TNF} \alpha$ in the culture supernatant of co-cultured cells by ELISA (Figure 3G and $\mathbf{H}$ ). Notably, similar to Figure S4A-C, S protein was not detected in the culture supernatant of cocultured cells as measured by ELISA (data not shown), suggesting that THP1 cells are activated by S protein-transfected epithelial cells through an unknown mechanism. To further confirm that S protein expressing epithelial cells can stimulate macrophages, we lysed HEK293T-S cells, and added the cell lysate to THP-1cells in culture (Figure S5A). Lysates of HEK293T-S cells efficiently induced inflammatory cytokines in THP-1 cells while no such induction was observed in response to cell lysate of HEK293T-GFP (Figure S5B). Together, these data imply that SARS- 
CoV-2 infected epithelial cells may stimulate macrophages and monocytes in a paracrine manner to produce inflammatory mediators.

\section{$S$ protein activates the $\mathrm{NF}-\kappa \mathrm{B}$ pathway}

Inflammatory genes are transcriptionally regulated by transcription factors that are activated by signaling pathways such as NF-кB, MAPK, STAT3, and AKT. To obtain further insight into how $\mathrm{S}$ protein induce the expression of inflammatory mediators, we stimulated THP1 cells with S2 protein. Cell lysates collected at various times following stimulation were analyzed for the activation of these inflammatory pathways by western blotting. As shown in Figure 4A, P65 and

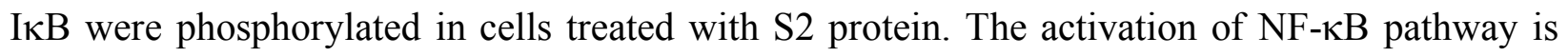
often accompanied by the activation of MAPK pathways, including ERK, P38 and JNK. Surprisingly, there was no activation of ERK and JNK in S2 stimulated cells (Figure 4A). There was no activation of the AKT pathway as well (Figure 4A), while STAT3 was phosphorylated at 2h following stimulation (Figure 4A). Inflammatory cytokines, such as IL-6, can activate STAT3; thus, the observed activation of STAT3 could be a secondary response of S protein-mediated

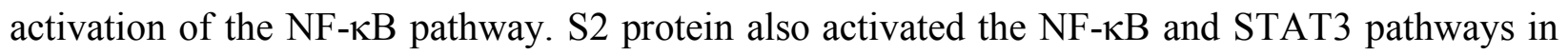

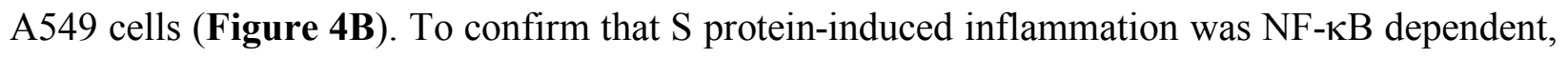
we inhibited the NF- $\kappa$ B pathway using Sc514, an inhibitor of IKK $\beta$, during stimulation with $\mathrm{S}$ protein. As expected, inhibition of the NF- $\mathrm{B}$ pathway abrogated inflammatory responses in $\mathrm{S}$ protein-stimulated macrophages (Figure 4C and D).

\section{S protein-mediated activation of the NF-kB pathway is TLR2 dependent}


Upon recognition of diverse PAMPs at the cell surface or in the endosome, TLRs activate the NF$\kappa \mathrm{B}$ and MAPK pathways through the adapter protein MyD88. To verify if TLR pathways are involved in S protein-mediated activation of the NF-אB pathway, we stimulated WT and $M y d 88^{-/-}$ BMDM with S2. Interestingly, there was no activation of the NF- $\kappa \mathrm{B}$ pathway in $M y d 88^{-/} \mathrm{BMDM}$ (Figure 5A). Consistently, there was no cytokine expression in $M y d 88^{-/}$macrophages upon stimulation with $\mathrm{S}$ protein (Figure 5B). This observation suggests that $\mathrm{S}$ protein-mediated activation of the NF- $\mathrm{BB}$ pathway involves TLR/MyDD88. We then interrogated which TLR sense S protein. Since $\mathrm{S}$ is a glycoprotein, we anticipated that TLR2, a receptor for lipoprotein, or TLR4, which senses lipopolysaccharide and several other stimuli (18), could be the immune sensor for S protein. Therefore, we stimulated $T l r 2^{-/-}$and $T l r 4^{-/-}$BMDMs with S2 protein and measured the

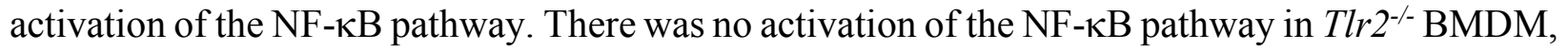
while activation of this pathway was intact in $T l r 4^{-/}$macrophages (Figure 5C). We confirmed that $T l r 2^{-/}$macrophages were defective in sensing Pam3CSK4, a ligand for TLR2, while they were fully responsive to TLR4 ligand LPS (Figure S6). Similar to S2, S1 protein activated the NF- $\mathrm{KB}$ pathway in WT macrophages but not $T l r 2^{-/}$macrophages (Figure 5D). Consistent with the defective activation of the NF- $\kappa$ B pathway, there was no induction of proinflammatory cytokines in S2-stimulated $T l r 2^{-/-}$macrophages (Figure 5E), suggesting that S protein induces inflammatory molecules via TLR2-dependent activation of the NF-אB pathway.

Finally, to understand whether S protein induce inflammation in vivo and what role TLR2 plays, we administered S1 and S2 proteins into WT or $T l r 2^{-/-}$mice intraperitoneally (i.p.). 16h following administration of S protein, we measured the cytokine IL-6, IL-1 $\beta$ and TNF $\alpha$ in the blood by ELISA before and after challenge with S protein. As shown in Figure 5F, the concentrations of 
IL-6, IL-1 $\beta$, and TNF $\alpha$ were elevated following S protein administration in WT mice, whereas no such induction of these cytokines was observed in $T l r 2^{-/-}$mice (Figure 5F). Together, these data suggest that TLR2 is the immune sensor for SARS-CoV-2 S protein, which potentially triggers inflammatory responses through the activation of the NF- $\kappa \mathrm{B}$ pathway.

\section{DISCUSSION}

Both SARS-CoV-2 infection and aberrant host immune responses are responsible for COVID-19 pathogenesis $(4,5,8,26)$. The initial host immune response against SARS-CoV-2 infection involves innate immune cells, such as macrophages, monocytes, neutrophils, and dendritic cells $(30,31)$. Cytokines, chemokines, and other inflammatory mediators produced by these cells inhibit virus replication, heal the damage, and activate the adaptive immune system. However, uncontrolled release of cytokines, chemokines, and reactive oxygen and nitrogen species often exert pathological consequences such as tissue injury, systemic inflammation, and organ failure $(4,5,8)$. Non-surviving COVID-19 patients exhibited massive influx of macrophages and neutrophils, but reduced T cells in their blood (30), pointing to the association of hyperactivation of innate immune cells with COVID-19 pathogenesis. Indeed, innate immune response is heightened in the lung of COVID-19 patients(31, 32). A better understanding of the mechanism through which SARS-CoV-2 stimulates innate immune cells and activates inflammatory signaling pathways are key to finding better treatment regimens for COVID-19. Our finding that SARSCoV-2 S protein is a potent viral PAMP involved in the induction of inflammatory cytokines and

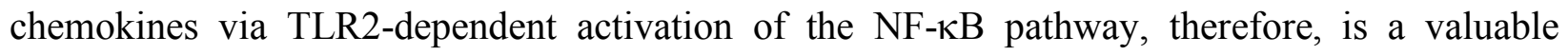
addition to the tremendous scientific effort aiming at combating COVID-19. 
Being an RNA virus, SARS-CoV-2 may activate RNA sensors TLR7, RIG-I and MDA5, which primarily responsible for production of type I interferons (17). Interestingly, type I interferon response is attenuated in COVID-19 patients and SARS-CoV-2 infected cells (8, 14). Transcriptomic analysis of bonchoalveolar lavage fluid and peripheral blood mononuclear cells of COVID-19 patients also demonstrated higher expression of proinflammatory cytokines and chemokines, but not type I interferons (32). Our knowledge on type I interferon response of SARSCoV-2 infected macrophages is limited. However, previous studies on SARS-CoV-1, which share $80 \%$ similarity with SARS-CoV-2, showed that macrophages and dendritic cells infected by SARS-CoV-1 produce chemokines CXCL10 and CCL2, but not type I interferons $(20,21)$. Lack of an interferon response can be explained by the fact that several structural and non-structural proteins including M, N, PLP, ORF3b, ORF6, and NSP1 inhibit type I interferon signaling (3338). Despite this evidence, the precise mechanism of excessive production of inflammatory cytokines along with reduced of type I interferons in COVID-19 patients remains elusive. In this regard, our findings that SARS-CoV-2 S protein is a potential trigger for proinflammatory cytokines and chemokines help understand why inflammatory response of COVID-19 is marked by elevated levels of proinflammatory cytokines and chemokines, but poor type I interferon response. Our findings suggest that S protein of SARS-CoV-1 and SARS-CoV-2 shares similar inflammatory function $(39,40)$. Further studies are required to clarify relative contribution of S protein, viral RNA, and other non-structural proteins in COVID-19 associated cytokine storm.

Inflammatory responses of COVID-19 patients are mostly implicated to innate immune cells, but they weakly express ACE2 (41). There is no strong evidence that SARS-CoV-2 infect and propagate in immune cells. Thus, it is intriguing how innate immune cells become activated to 
produce inflammatory mediators during SARS-CoV-2 infection. We propose three mechanisms involved in hyperinflammatory response during SARS-CoV-2 infection. First, innate immune cells like macrophages and monocytes recognize S protein of SARS-CoV-2 at the cell surface through TLR2, leading to the activation of the NF- $\kappa B$ pathway. Immune sensing of $\mathrm{S}$ protein is likely independent of ACE2 since mouse macrophages, whose ACE2 receptor does not bind to S protein, express inflammatory cytokines and chemokines in response to S protein. Second, innate immune cells get activated by virally infected epithelial cells. Our data suggest that epithelial cells expressing $\mathrm{S}$ protein in the cytosol can activate macrophage when they physically interact. Although the underlying mechanism is not clear, macrophage may engulf or recognize cell surface molecule expressed on SARS-CoV-2 infected epithelial cells. In a third mechanism, like myeloid cells, epithelial cells can be activated by $\mathrm{S}$ protein extracellularly, leading to the induction of proinflammatory cytokines and chemokines. Although inflammatory responses of epithelial cells are weaker than that of innate immune cells, epithelial cell-derived chemokines recruit neutrophils, monocytes and lymphocytes in SARS-CoV2-infected lungs and thereby contribute to immunopathology of COVID-19 patients.

Our data demonstrate that TLR2 is the innate immune sensor for the S protein. Like other MyD88dependent TLR pathways, ligation of TLR2 leads to the activation of transcription factors NF- $\mathrm{B}$ and AP-1 (17). Interestingly, while there was activation of NF- $\mathrm{B}, \mathrm{AP}-1$ upstream signaling kinases such as ERK and JNK were not seen activated by S proteins. SARS-CoV-1 S protein activates the NF- $\kappa$ B pathway in human monocyte derived macrophages (39, 40). COVID-19

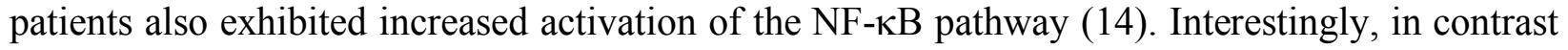
to these findings, a separate study reported that SARS-CoV-1 S protein expressing baculovirus 
activates AP-1 but not NF- $\kappa$ B in A549 cells (42). Future studies dissecting the signaling pathway regulated by S protein of SARS-CoV-1 and CoV-2 may reveal further insight.

In summary, this study documents a potential mechanism for the inflammatory response induced by SARS-CoV-2. We demonstrate that SARS-CoV-2 S protein is a potent viral PAMP that upon sensing by TLR2 activates the NF- $\mathrm{B}$ pathway, leading to the expression of inflammatory mediators in innate immune and epithelial cells. The effort so far in combating the COVID-19 pandemic is unprecedented, making it possible for the development of a number of vaccines within a year of outbreak. Since $\mathrm{S}$ protein is being targeted by most of the vaccine candidates, it is important to consider its inflammatory function in vaccine design. Considering the fact that new variants of SARS-CoV-2 with mutations in the S protein spread more easily and may confer more severe disease, the effectiveness of current vaccines remain uncertain (43). Thus, the importance of developing therapeutic drugs for COVID-19 remains high. This study suggests that TLR2 or its downstream signaling adapters could be therapeutically targeted to mitigate hyperinflammatory response in COVID-19 patients.

\section{MATERIALS AND METHODS}

\section{Mice}

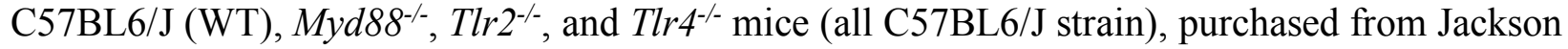
Laboratory were used in this study. All mice were bred and maintained in a specific pathogen-free (SPF) facility at the UT Southwestern Medical Center. All studies were approved by the Institutional Animal Care and Use Committee (IACUC) and were conducted in accordance with 
the IACUC guidelines and the National Institutes of Health Guide for the Care and Use of Laboratory Animals. All experimental groups were conducted with age and sex-matched male and female mice.

\section{Cell culture and maintenance}

The human embryonic kidney epithelial cell line HEK293T (ATCC, CRL-3216), and human lung epithelial cell line A549 (ATCC, CCL-185) were cultured in Dulbecco's Modified Eagle's medium (DMEM; high glucose, Sigma) supplemented with 10\% (v/v) FBS (Sigma) and 1\% (v/v) PenStrep (Sigma) and maintained in a $5 \% \mathrm{CO}_{2}$ incubator at $37^{\circ} \mathrm{C}$. THP1 (ATCC, CRL-TIB-202) cells were cultured in Roswell Park Memorial Institute (RPMI)-1640 medium (R8758, Sigma) supplemented with 10\% (v/v) FBS (Sigma) and 1\% (v/v) PenStrep (Sigma) and maintained in a $5 \% \mathrm{CO}_{2}$ incubator at $37^{\circ} \mathrm{C}$. Each cell lines were confirmed free from mycoplasma contamination by testing with mycoplasma detection kit (Sigma).

\section{In vitro studies with THP-1 macrophage-like cells}

THP-1 cells were cultured in culture medium containing final concentration of $100 \mathrm{ng} / \mathrm{mL}$ of phorbol-12-myristate 13-acetate (PMA; tlrl, Invivogen). Following 24h post PMA treatment, THP-1 macrophage-like cells were washed with pre-warmed RPMI-1640 containing 10\% FBS and 1\% penicillin-streptomycin and allowed to grow in PMA-free culture medium for next 12 hrs. To examine the effect of SARS-CoV-2 structural proteins on inflammatory responses, THP-1 macrophage-like cells were stimulated with SARS-CoV-2 S1 (RayBiotech, 230-30161), SARSCoV-2 S2 (RayBiotech, 230-30163), SARS-CoV-2 N (RayBiotech, 230-30164), SARS-CoV-2 M (MyBioSource, MBS8574735) and SARS-CoV-2 E (MyBioSource, MBS9141944) for 4 hrs. 


\section{Culture of mouse bone marrow-derived macrophage (BMDM)}

Mouse bone marrow cells were collected as described previously (44). Bone marrow cells were cultured in L-cell-conditioned IMDM medium supplemented with 10\% FBS, 1\% nonessential amino acid, and 1\% penicillin-streptomycin for 6 days to differentiate into macrophages. BMDMs were seeded in 12 -well cell culture plates at a concentration of $1.2 \times 10^{6}$ cell/well and incubated overnight before in vitro studies. BMDMs were stimulated as described above.

\section{cDNA constructs and transient transfection}

At $50-60 \%$ confluency, HEK293T and A549 cells were transfected with GFP-Flag (VB200507$2985 \mathrm{cmv})$ or SARS-CoV-2 S-Flag (VB200507-2984jyv) (1.5 $\mu \mathrm{g} / \mathrm{ml})$ constructs using Lipofectamine 3000 reagent (Invitrogen) according to manufacturer`s instructions, and confirmed by observing GFP under fluorescence microscope and western blot analysis of SARS-CoV-2 S and Flag proteins. 48h post transfection, cells were lysed with RIPA lysis buffer containing complete protease inhibitor cocktail and phosphatase inhibitor cocktail (Roche) for the detection of S protein by western blot or ELISA, or resuspended in TRIzol ${ }^{\mathrm{TM}}$ reagent (Invitrogen) for the isolation of RNA and subsequent measurement of S mRNA by real-time qPCR.

\section{In-vitro stimulation of epithelial cells}

To examine the effect of SARS-CoV-2 proteins on inflammatory responses in epithelial cells, HEK293T and A549 cells were stimulated with SARS-CoV-2 S1 (RayBiotech, 230-30161), SARS-CoV-2 S2 (Ray Biotech, 230-30163) for 4 hrs. RNA was isolated and measured for the expression inflammatory genes by real-time PCR 


\section{Co-culture of macrophages and epithelial cells}

HEK293T-GFP and HEK293T-SARS-CoV-2 S or A549-GFP and A549-SARS-CoV-2 S cells were cultured with THP-1 macrophage-like cells in a ratio of 1:2 (macrophages were twice in number to epithelial cells). Following $16 \mathrm{~h}$ of co-culture, culture medium was collected, filtered with $0.2 \mu \mathrm{M}$ filter, and used for ELISA. RNA was isolated and measured for the expression inflammatory genes by real-time PCR.

\section{Stimulation of macrophages with conditioned medium of S-protein expressed epithelial cells}

At $50-60 \%$ confluency, HEK293T and A549 cells were transfected with GFP-Flag or SARSCoV-2 S-Flag $(1.5 \mu \mathrm{g} / \mathrm{ml})$ constructs using Lipofectamine 3000 reagent (Invitrogen) according to manufacturer`s instructions, and confirmed by observing GFP under fluorescence microscope and western blot analysis of SARS-CoV-2 $\mathrm{S}$ and Flag. 48h post-transfection, culture medium (conditioned medium) was collected, filtered with $0.2 \mu \mathrm{M}$ filter and store at $-80{ }^{\circ} \mathrm{C}$. At about $85 \%$ confluency, culture medium of macrophage like THP-1 cells were replaced with new media containing $30 \%(\mathrm{~V} / \mathrm{V})$ of epithelial cell conditioned medium. After $4 \mathrm{~h}$ incubation with conditioned medium, the expression of inflammatory cytokines and chemokines were measured.

\section{Real-time PCR}

Epithelial cells, BMDMs, and THP-1 macrophage-like cells, RAW264.7 cells were lysed in

TRIzol $^{\mathrm{TM}}$ reagent (Invitrogen). Total RNA was isolated using TRIzol ${ }^{\mathrm{TM}}$ reagent (Invitrogen) following the manufacturer's instructions. Isolated RNA was reverse transcribed into cDNA using iScript (Bio-Rad). Real-time PCR was performed using iTaq Universal SYBR Green Supermix 
(Bio-Rad). Individual expression data was normalized to GAPDH as described earlier (45). Primers used for qRT-PCR are listed in Table S1.

\section{In-vitro studies with human peripheral blood mononuclear cells (PBMCs)}

Human PBMCs were obtained from STEMCELL ${ }^{\mathrm{TM}}$ TECHNOLOGIES (70025), and were cultured in RPMI-1640 medium (R8758, Sigma) supplemented with 10\% (v/v) FBS (Sigma) and $1 \%(\mathrm{v} / \mathrm{v})$ PenStrep (Sigma) and maintained in a 5\% $\mathrm{CO}_{2}$ incubator at $37^{\circ} \mathrm{C}$. After $48 \mathrm{~h}$, hPBMCs were centrifuged and resuspended in fresh medium for $3 \mathrm{~h}$, and then stimulated with SARS-CoV$2 \mathrm{~S}(500 \mathrm{ng} / \mathrm{mL})$ for $4 \mathrm{hrs}$.

\section{Inflammatory response of SARS-CoV-2 S protein in mice}

WT and Tlr2 $2^{--}$mice were intraperitoneally injected with S1 and S2 subunits of SARS-CoV-2 S protein at equal concentration (1ug each/mouse). Blood was collected before $\mathrm{S}$ protein administration by cheek puncturing. $15 \mathrm{~h}$ following treatment, mice were sacrificed, and blood was drawn from the heart. Serum was separated from the blood by centrifugation and used for the measurement of cytokines by ELISA.

\section{ELISA}

BMDMs and THP-1 macrophage-like cells were lysed in ice-cold RIPA buffer supplemented with complete protease inhibitor and phosphatase inhibitor cocktails (Roche). Protein concentration was measured by the Pierce ${ }^{\mathrm{TM}}$ BCA Protein Assay Kit (Thermo Scientific-23227). Serum was isolated from mouse blood by centrifugation at 10,000 RPM for $10 \mathrm{~min}$ at $4^{\circ} \mathrm{C}$. The concentration of IL-6, IL-1 $\beta$, and TNF- $\alpha$ in cell culture medium and serum was measured using commercially 
available ELISA kits (R\&D Systems). SARS-CoV-2 S protein in cell lysates was detected by SARS-CoV-2 S ELISA kit and following manufacturer's instruction (RayBiotech, ELVCOVID19S2).

\section{Western blot}

THP-1 macrophage-like cells, BMDM, HEK293T and A549 cells were lysed in ice-cold RIPA lysis buffer containing complete protease inhibitor and phosphatase inhibitor cocktails (Roche), resolved by SDS-PAGE, and transferred onto a PVDF membrane. The membranes were immunoblotted with antibodies against Phospho-NF-kB p65 (3033, Cell Signaling), Phospho-

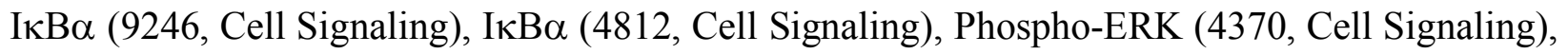
ERK (4695, Cell Signaling), Phospho-JNK (4668, Cell Signaling), Phospho-AKT (4060, Cell Signaling), AKT (9272, Cell Signaling), Phospho-STAT3 (9145, Cell Signaling), Flag®M2 (F1804, Sigma-Aldrich), SARS-CoV-2 S (GTX632605, GeneTex) and $\beta$-actin (A2228, Sigma). Immunoreactive protein bands were detected using ECL super signal west femto substrate reagent (Thermo Scientific).

\section{Flow cytometric analysis of SARS-CoV-2 overexpressed HEK293T cells}

HEK293T cells were transfected with SARS-CoV-2 plasmid. 48 hours following transfection, cells were trypsinized and processed for cell surface staining. Briefly, $0.5 \times 10^{6}$ cells were resuspended in staining buffer (00-4222-26; eBioscience) and centrifuged at 1500 RPM for 3 min at $4{ }^{\circ} \mathrm{C}$. Cells were then incubated with Fc block CD16/32 monoclonal antibody (14-0161-82, eBioscience) and stained with primary antibody SARS-CoV-2 (GTX632604, GeneTex) for $30 \mathrm{~min}$ on ice. After washing with staining buffer once, cells were stained with secondary antibody 
DyLight 488 (35552, Thermo Scientific) on ice for 1h. Finally, cells were washed twice with staining buffer and acquired in flow cytometer (CytoFLEX-Beckman Coulter). Flow cytometric data were analyzed by FlowJo software.

\section{Heat inactivation of S2 protein}

$\mathrm{S} 2$ protein was heated at $95 \mathrm{C}$ for $30 \mathrm{in}$. Native of heat-denatured $\mathrm{S} 2$ proteins $(500 \mathrm{ng} / \mathrm{ml})$ were used to stimulate THP1 cells and measurement of Cytokines by real-time PCR.

\section{Statistical Analysis}

Data are represented as mean \pm SD or SEM. Data were analyzed by Prism8 (GraphPad Software) and statistical significance was determined by two-tailed unpaired Student's $t$ test. $p<0.05$ was considered statistically significant.

\section{ACKNOWLEDGEMENT}

We would like to thank the UT Southwestern Animal Resource Center (ARC) for maintenance and care of our mouse colony. We thank Dr. Zhijian "James" Chen for sharing $M y d 88^{-/-}$mice and Dr. Esra Akbay for sharing A549 cells. Hasan Zaki is supported by The National Institute of Diabetes and Digestive and Kidney Diseases (NIDDK) of the National Institute of Health (NIH) under Award Number R01DK125352 and Cancer Prevention and Research Institute of Texas (CPRIT) Individual Investigator Award (RP200184). Rashmin C. Savani holds the William Buchanan Chair in Pediatrics and is funded by a Sponsored Research Agreement with Mallinckrodt Pharmaceuticals, Inc for an unrelated project. 
Author contributions: S.K. designed and performed experiments, and analyzed data, and helped in manuscript writing. M.S.S. and C.L. helped in experiment. R.C.S. provided Tlr2 ${ }^{-/}$mice. J.S. and R.C.S. helped in experimental design, and reviewed the manuscript. H.Z. conceived the study, designed experiments, and wrote the manuscript.

\section{REFERENCES}

1. Zhou P, Yang XL, Wang XG, Hu B, Zhang L, Zhang W, Si HR, Zhu Y, Li B, Huang CL, Chen HD, Chen J, Luo Y, Guo H, Jiang RD, Liu MQ, Chen Y, Shen XR, Wang X, Zheng XS, Zhao K, Chen QJ, Deng F, Liu LL, Yan B, Zhan FX, Wang YY, Xiao GF, Shi ZL. 2020. A pneumonia outbreak associated with a new coronavirus of probable bat origin. Nature 579:270-273.

2. Wu F, Zhao S, Yu B, Chen YM, Wang W, Song ZG, Hu Y, Tao ZW, Tian JH, Pei YY, Yuan ML, Zhang YL, Dai FH, Liu Y, Wang QM, Zheng JJ, Xu L, Holmes EC, Zhang YZ. 2020. A new coronavirus associated with human respiratory disease in China. Nature 579:265-269.

3. Huang C, Wang Y, Li X, Ren L, Zhao J, Hu Y, Zhang L, Fan G, Xu J, Gu X, Cheng Z, Yu T, Xia J, Wei Y, Wu W, Xie X, Yin W, Li H, Liu M, Xiao Y, Gao H, Guo L, Xie J, Wang G, Jiang R, Gao Z, Jin Q, Wang J, Cao B. 2020. Clinical features of patients infected with 2019 novel coronavirus in Wuhan, China. Lancet 395:497-506.

4. Vabret N, Britton GJ, Gruber C, Hegde S, Kim J, Kuksin M, Levantovsky R, Malle L, Moreira A, Park MD, Pia L, Risson E, Saffern M, Salome B, Esai Selvan M, Spindler MP, Tan J, van der Heide V, Gregory JK, Alexandropoulos K, Bhardwaj N, Brown BD, Greenbaum B, Gumus ZH, Homann D, Horowitz A, Kamphorst AO, Curotto de Lafaille MA, Mehandru S, Merad M, Samstein RM, Sinai Immunology Review P. 2020. Immunology of COVID-19: Current State of the Science. Immunity 52:910-941.

5. Tay MZ, Poh CM, Renia L, MacAry PA, Ng LFP. 2020. The trinity of COVID-19: immunity, inflammation and intervention. Nat Rev Immunol 20:363-374.

6. Li Y, Li H, Li M, Zhang L, Xie M. 2020. The prevalence, risk factors and outcome of cardiac dysfunction in hospitalized patients with COVID-19. Intensive Care Med 46:20962098.

7. Gu J, Gong E, Zhang B, Zheng J, Gao Z, Zhong Y, Zou W, Zhan J, Wang S, Xie Z, Zhuang H, Wu B, Zhong H, Shao H, Fang W, Gao D, Pei F, Li X, He Z, Xu D, Shi X, Anderson VM, Leong AS. 2005. Multiple organ infection and the pathogenesis of SARS. J Exp Med 202:415-24.

8. Blanco-Melo D, Nilsson-Payant BE, Liu WC, Uhl S, Hoagland D, Moller R, Jordan TX, Oishi K, Panis M, Sachs D, Wang TT, Schwartz RE, Lim JK, Albrecht RA, tenOever BR. 2020. Imbalanced Host Response to SARS-CoV-2 Drives Development of COVID-19. Cell 181:1036-1045 e9.

9. Hoffmann M, Kleine-Weber H, Schroeder S, Kruger N, Herrler T, Erichsen S, Schiergens TS, Herrler G, Wu NH, Nitsche A, Muller MA, Drosten C, Pohlmann S. 2020. SARS- 
CoV-2 Cell Entry Depends on ACE2 and TMPRSS2 and Is Blocked by a Clinically Proven Protease Inhibitor. Cell 181:271-280 e8.

10. Walls AC, Park YJ, Tortorici MA, Wall A, McGuire AT, Veesler D. 2020. Structure, Function, and Antigenicity of the SARS-CoV-2 Spike Glycoprotein. Cell 181:281-292 e6.

11. Xu Z, Shi L, Wang Y, Zhang J, Huang L, Zhang C, Liu S, Zhao P, Liu H, Zhu L, Tai Y, Bai C, Gao T, Song J, Xia P, Dong J, Zhao J, Wang FS. 2020. Pathological findings of COVID-19 associated with acute respiratory distress syndrome. Lancet Respir Med 8:420422.

12. Wang D, Hu B, Hu C, Zhu F, Liu X, Zhang J, Wang B, Xiang H, Cheng Z, Xiong Y, Zhao Y, Li Y, Wang X, Peng Z. 2020. Clinical Characteristics of 138 Hospitalized Patients With 2019 Novel Coronavirus-Infected Pneumonia in Wuhan, China. JAMA 323:1061-1069.

13. Mehta P, McAuley DF, Brown M, Sanchez E, Tattersall RS, Manson JJ, Hlh Across Speciality Collaboration UK. 2020. COVID-19: consider cytokine storm syndromes and immunosuppression. Lancet 395:1033-1034.

14. Hadjadj J, Yatim N, Barnabei L, Corneau A, Boussier J, Smith N, Pere H, Charbit B, Bondet V, Chenevier-Gobeaux C, Breillat P, Carlier N, Gauzit R, Morbieu C, Pene F, Marin N, Roche N, Szwebel TA, Merkling SH, Treluyer JM, Veyer D, Mouthon L, Blanc C, Tharaux PL, Rozenberg F, Fischer A, Duffy D, Rieux-Laucat F, Kerneis S, Terrier B. 2020. Impaired type I interferon activity and inflammatory responses in severe COVID-19 patients. Science 369:718-724.

15. Khan S, Godfrey V, Zaki MH. 2019. Cytosolic Nucleic Acid Sensors in Inflammatory and Autoimmune Disorders. Int Rev Cell Mol Biol 344:215-253.

16. Park A, Iwasaki A. 2020. Type I and Type III Interferons - Induction, Signaling, Evasion, and Application to Combat COVID-19. Cell Host Microbe 27:870-878.

17. Kawasaki T, Kawai T. 2014. Toll-like receptor signaling pathways. Front Immunol 5:461.

18. Kawai T, Akira S. 2006. TLR signaling. Cell Death Differ 13:816-25.

19. Jensen S, Thomsen AR. 2012. Sensing of RNA viruses: a review of innate immune receptors involved in recognizing RNA virus invasion. J Virol 86:2900-10.

20. Cheung CY, Poon LL, Ng IH, Luk W, Sia SF, Wu MH, Chan KH, Yuen KY, Gordon S, Guan Y, Peiris JS. 2005. Cytokine responses in severe acute respiratory syndrome coronavirus-infected macrophages in vitro: possible relevance to pathogenesis. J Virol 79:7819-26.

21. Law HK, Cheung CY, Ng HY, Sia SF, Chan YO, Luk W, Nicholls JM, Peiris JS, Lau YL. 2005. Chemokine up-regulation in SARS-coronavirus-infected, monocyte-derived human dendritic cells. Blood 106:2366-74.

22. de Wit E, van Doremalen N, Falzarano D, Munster VJ. 2016. SARS and MERS: recent insights into emerging coronaviruses. Nat Rev Microbiol 14:523-34.

23. Li W, Moore MJ, Vasilieva N, Sui J, Wong SK, Berne MA, Somasundaran M, Sullivan JL, Luzuriaga K, Greenough TC, Choe H, Farzan M. 2003. Angiotensin-converting enzyme 2 is a functional receptor for the SARS coronavirus. Nature 426:450-4.

24. Bertram S, Glowacka I, Muller MA, Lavender H, Gnirss K, Nehlmeier I, Niemeyer D, He Y, Simmons G, Drosten C, Soilleux EJ, Jahn O, Steffen I, Pohlmann S. 2011. Cleavage and activation of the severe acute respiratory syndrome coronavirus spike protein by human airway trypsin-like protease. J Virol 85:13363-72.

25. Shirato K, Matsuyama S, Ujike M, Taguchi F. 2011. Role of proteases in the release of porcine epidemic diarrhea virus from infected cells. J Virol 85:7872-80. 
26. Grant RA, Morales-Nebreda L, Markov NS, Swaminathan S, Querrey M, Guzman ER, Abbott DA, Donnelly HK, Donayre A, Goldberg IA, Klug ZM, Borkowski N, Lu Z, Kihshen H, Politanska Y, Sichizya L, Kang M, Shilatifard A, Qi C, Lomasney JW, Argento AC, Kruser JM, Malsin ES, Pickens CO, Smith SB, Walter JM, Pawlowski AE, Schneider D, Nannapaneni P, Abdala-Valencia H, Bharat A, Gottardi CJ, Budinger GRS, Misharin AV, Singer BD, Wunderink RG, Investigators NSS. 2021. Circuits between infected macrophages and T cells in SARS-CoV-2 pneumonia. Nature 590:635-641.

27. Xiao F, Tang M, Zheng X, Liu Y, Li X, Shan H. 2020. Evidence for Gastrointestinal Infection of SARS-CoV-2. Gastroenterology 158:1831-1833 e3.

28. Hamming I, Timens W, Bulthuis ML, Lely AT, Navis G, van Goor H. 2004. Tissue distribution of ACE2 protein, the functional receptor for SARS coronavirus. A first step in understanding SARS pathogenesis. J Pathol 203:631-7.

29. Varga Z, Flammer AJ, Steiger P, Haberecker M, Andermatt R, Zinkernagel AS, Mehra MR, Schuepbach RA, Ruschitzka F, Moch H. 2020. Endothelial cell infection and endotheliitis in COVID-19. Lancet 395:1417-1418.

30. Liao M, Liu Y, Yuan J, Wen Y, Xu G, Zhao J, Cheng L, Li J, Wang X, Wang F, Liu L, Amit I, Zhang S, Zhang Z. 2020. Single-cell landscape of bronchoalveolar immune cells in patients with COVID-19. Nat Med 26:842-844.

31. Zhou Z, Ren L, Zhang L, Zhong J, Xiao Y, Jia Z, Guo L, Yang J, Wang C, Jiang S, Yang D, Zhang G, Li H, Chen F, Xu Y, Chen M, Gao Z, Yang J, Dong J, Liu B, Zhang X, Wang W, He K, Jin Q, Li M, Wang J. 2020. Heightened Innate Immune Responses in the Respiratory Tract of COVID-19 Patients. Cell Host Microbe 27:883-890 e2.

32. Xiong Y, Liu Y, Cao L, Wang D, Guo M, Jiang A, Guo D, Hu W, Yang J, Tang Z, Wu H, Lin Y, Zhang M, Zhang Q, Shi M, Liu Y, Zhou Y, Lan K, Chen Y. 2020. Transcriptomic characteristics of bronchoalveolar lavage fluid and peripheral blood mononuclear cells in COVID-19 patients. Emerg Microbes Infect 9:761-770.

33. Siu KL, Chan CP, Kok KH, Chiu-Yat Woo P, Jin DY. 2014. Suppression of innate antiviral response by severe acute respiratory syndrome coronavirus $\mathrm{M}$ protein is mediated through the first transmembrane domain. Cell Mol Immunol 11:141-9.

34. Frieman M, Ratia K, Johnston RE, Mesecar AD, Baric RS. 2009. Severe acute respiratory syndrome coronavirus papain-like protease ubiquitin-like domain and catalytic domain regulate antagonism of IRF3 and NF-kappaB signaling. J Virol 83:6689-705.

35. Narayanan K, Huang C, Lokugamage K, Kamitani W, Ikegami T, Tseng CT, Makino S. 2008. Severe acute respiratory syndrome coronavirus nsp1 suppresses host gene expression, including that of type I interferon, in infected cells. J Virol 82:4471-9.

36. Devaraj SG, Wang N, Chen Z, Chen Z, Tseng M, Barretto N, Lin R, Peters CJ, Tseng CT, Baker SC, Li K. 2007. Regulation of IRF-3-dependent innate immunity by the papain-like protease domain of the severe acute respiratory syndrome coronavirus. J Biol Chem 282:32208-21.

37. Frieman M, Yount B, Heise M, Kopecky-Bromberg SA, Palese P, Baric RS. 2007. Severe acute respiratory syndrome coronavirus ORF6 antagonizes STAT1 function by sequestering nuclear import factors on the rough endoplasmic reticulum/Golgi membrane. J Virol 81:9812-24.

38. Kopecky-Bromberg SA, Martinez-Sobrido L, Frieman M, Baric RA, Palese P. 2007. Severe acute respiratory syndrome coronavirus open reading frame (ORF) 3b, ORF 6, and nucleocapsid proteins function as interferon antagonists. J Virol 81:548-57. 
39. Wang W, Ye L, Ye L, Li B, Gao B, Zeng Y, Kong L, Fang X, Zheng H, Wu Z, She Y. 2007. Up-regulation of IL-6 and TNF-alpha induced by SARS-coronavirus spike protein in murine macrophages via NF-kappaB pathway. Virus Res 128:1-8.

40. Dosch SF, Mahajan SD, Collins AR. 2009. SARS coronavirus spike protein-induced innate immune response occurs via activation of the NF-kappaB pathway in human monocyte macrophages in vitro. Virus Res 142:19-27.

41. Ropa J, Cooper S, Capitano ML, Van't Hof W, Broxmeyer HE. 2020. Human Hematopoietic Stem, Progenitor, and Immune Cells Respond Ex Vivo to SARS-CoV-2 Spike Protein. Stem Cell Rev Rep doi:10.1007/s12015-020-10056-Z.

42. Chang YJ, Liu CY, Chiang BL, Chao YC, Chen CC. 2004. Induction of IL-8 release in lung cells via activator protein-1 by recombinant baculovirus displaying severe acute respiratory syndrome-coronavirus spike proteins: identification of two functional regions. J Immunol 173:7602-14.

43. Plante JA, Liu Y, Liu J, Xia H, Johnson BA, Lokugamage KG, Zhang X, Muruato AE, Zou J, Fontes-Garfias CR, Mirchandani D, Scharton D, Bilello JP, Ku Z, An Z, Kalveram B, Freiberg AN, Menachery VD, Xie X, Plante KS, Weaver SC, Shi PY. 2020. Spike mutation D614G alters SARS-CoV-2 fitness. Nature doi:10.1038/s41586-020-2895-3.

44. Udden SMN, Peng L, Gan JL, Shelton JM, Malter JS, Hooper LV, Zaki MH. 2017. NOD2 Suppresses Colorectal Tumorigenesis via Downregulation of the TLR Pathways. Cell Rep 19:2756-2770.

45. Hu S, Peng L, Kwak YT, Tekippe EM, Pasare C, Malter JS, Hooper LV, Zaki MH. 2015. The DNA Sensor AIM2 Maintains Intestinal Homeostasis via Regulation of Epithelial Antimicrobial Host Defense. Cell Rep 13:1922-36.

\section{FIGURE LEGENDS}

Figure 1. SARS-CoV-2 S protein induces cytokines and chemokines in macrophages and

monocytes. (A) Human monocytic cells THP1-derived macrophages were stimulated with recombinant $\mathrm{S} 1, \mathrm{~S} 2, \mathrm{M}, \mathrm{N}$, and $\mathrm{E}$ proteins of SARS-CoV-2 at a concentration of $500 \mathrm{ng} / \mathrm{ml}$. Four hours post stimulation, the expression of $I L 6, I L 1 b, T N F a, C X C L 1, C X C L 2, C C l 2, I F N a, I F N b$, and IFNg was measured by real-time qPCR. (B) THP-1 cells were stimulated with S2 protein (500ng/ml). At indicated times, RNA was isolated and measured for $I L 6, I L 1 b, T N F a, C X C L 1$, and CXCL2 by real-time qPCR. (C) THP-1 cells were stimulated with S2 protein at various concentration for $4 \mathrm{~h}$, and measured the indicated cytokines by real-time qPCR. (D) Human 
peripheral blood mononuclear cells $(\mathrm{PBMC})$ were incubated with $\mathrm{S} 2$ protein for $4 \mathrm{~h}$. The expression of $I L 6, I L 1 b, T N F a, C X C L 1$, and $C X C L 2$ was measured by real-time qPCR. Data represent mean $\pm \mathrm{SD}(\mathrm{n}=3) ;{ }^{*} p<0.05,{ }^{* *} p<0.001, * * * p<0.0001, * * * * p<0.00001$ by unpaired Student's $t$ test. Experiments were repeated two times and data of a representative experiment is presented.

Figure 2. Lung epithelial cells produce inflammatory molecules in response to SARS-CoV-2 S protein. (A) A549 cells were incubated with SARS-CoV-2 S2 (500 ng/ml) protein for 12 and 24h. RNA was isolated and measured for the expression of inflammatory cytokines and chemokines. (B-C) SARS-CoV-2 S protein was overexpressed in HEK293T and A549 cells. 48h following transfection with expression plasmids, the mRNA levels of IL6, ILIb, TNFa, CXCL1, and $C X C L 2$ were measured. Data represent mean $\pm \mathrm{SD}(\mathrm{n}=3)$. Experiments were repeated two times and data of a representative experiment is presented.

Figure 3. Macrophages get stimulated by epithelial cells expressing $\mathbf{S}$ protein. (A-C) SARSCoV-2 S2 protein was overexpressed in either HEK293T or A549 cells. Forty eight hours following transfection with S2 or GFP plasmids, cell culture supernatants were collected and added into THP1 cell cultures at 30\% V/V. (B-C) 4h post incubation, the expression of IL6, ILIb, and TNFa in THP1 cells treated with culture supernatant of HEK293T (B) or A549 (C) was measured by real-time qPCR. (D) HEK293 or A549 cells expressing S protein were co-cultured with THP1 cells at 1:2 ratio for $16 \mathrm{~h}$. (E-F) The expression of $I L 6, I L 1 b$, and $T N F a$ were measured by realtime PCR. (G-H) Protein levels of $I L-6, I L-1 \beta$, and $T N F \alpha$ in culture supernatant described in D were measured by ELISA. Data represent mean $\pm \mathrm{SD}(\mathrm{n}=3) ;{ }^{*} p<0.05,{ }^{*} * p<0.001, * * * p<0.0001$ 
by unpaired Student's $t$ test. Experiments were repeated two times and data of a representative experiment is presented.

Figure 4. SARS-CoV-2 S protein activates the NF-אB pathway. (A-B) THP1 and A549 cells were stimulated with S2 $(500 \mathrm{ng} / \mathrm{ml})$ for indicated time points. Phosphorylation of P65, I $\kappa \mathrm{B} \alpha$, ERK, JNK, STAT3, and AKT was measured by western blotting. (C-D) THP1 cells were stimulated by SARS-CoV-2 S2 protein $(500 \mathrm{ng} / \mathrm{ml})$ in the presence or absence of IKK $\beta$ inhibitor sc514. (B) Phosphorylation of P65 and $\mathrm{I} \kappa \mathrm{B} \alpha$ was measured by Western blotting. (E) The expression of $I L 6, I L 1 b$ and TNFa in stimulated THP1 cells was measured by real-time qPCR. Data represent mean $\pm \mathrm{SD}(\mathrm{n}=3) ;{ }^{*} p<0.05, * * p<0.001, * * * p<0.0001$ by unpaired Student's $t$ test. Experiments were repeated two times and data of a representative experiment is presented.

Figure 5. TLR2 recognizes SARS-CoV-2 S protein and activate the NF- $\kappa$ B pathway. (A-B) Bone marrow derived macrophages (BMDMs) from WT and $M y d 88^{-/-}$mice were stimulated with

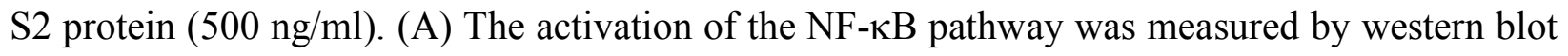
analysis of P-P65 and P-Iкb $\alpha$. (B) The induction of Il6, Illb and Tnfa was measured by real-time PCR. (C) BMDMs from WT, $T l r 2^{-/}$and $T l r 4^{-/-}$mice were treated with S2 protein $(500 \mathrm{ng} / \mathrm{ml})$. Cell lysates collected at different times were analyzed for the activation of the NF- $\kappa$ B pathway by

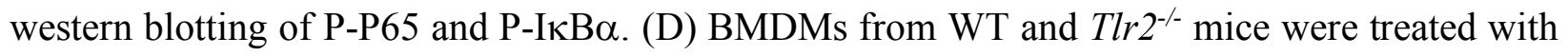
$\mathrm{S} 1$ protein, and the activation of $\mathrm{P} 65$ and $\mathrm{I} \kappa \mathrm{B}$ was measured by western blotting. (E) WT, Tlr2 $2^{-/}$ and $T l r 4^{-/-}$macrophages were treated with S2 protein $(500 \mathrm{ng} / \mathrm{ml})$. The expression of cytokines was measured by real-time PCR at $4 \mathrm{~h}$ post stimulation. Data represent mean $\pm \mathrm{SD}(\mathrm{n}=3) ; * * * p<$ $0.0001, * * * * p<0.00001$ by unpaired Student's $t$ test. Experiments were repeated two times and 
data of a representative experiment is presented. (F) WT and $T l r 2^{-/}$mice were administered with $\mathrm{S} 1$ and $\mathrm{S} 2$ protein $(1 \mu \mathrm{g}$ each/mouse). Blood collected before and 16h post S protein administration was measured for IL-6, IL-1 $\beta$, and TNF $\alpha$ by ELISA. Data represent mean \pm SEM (n=5); *** $p<$ $0.0001, * * * * p<0.00001$ by unpaired Student's $t$ test. Experiments were repeated two times and data of a representative experiment is presented. 
bioRxiv preprint dol: https://doi.org/10.1101/2021.03.16.435700; this version posted March 17, 2021. The copyright holder for this preprint (which was not certified by peer review) is the author/funder, who has granted bioRxiv a license to display the preprint in perpetuity. It is made available under aCC-BY-NC-ND 4.0 International license.

Figure 1

A THP-1
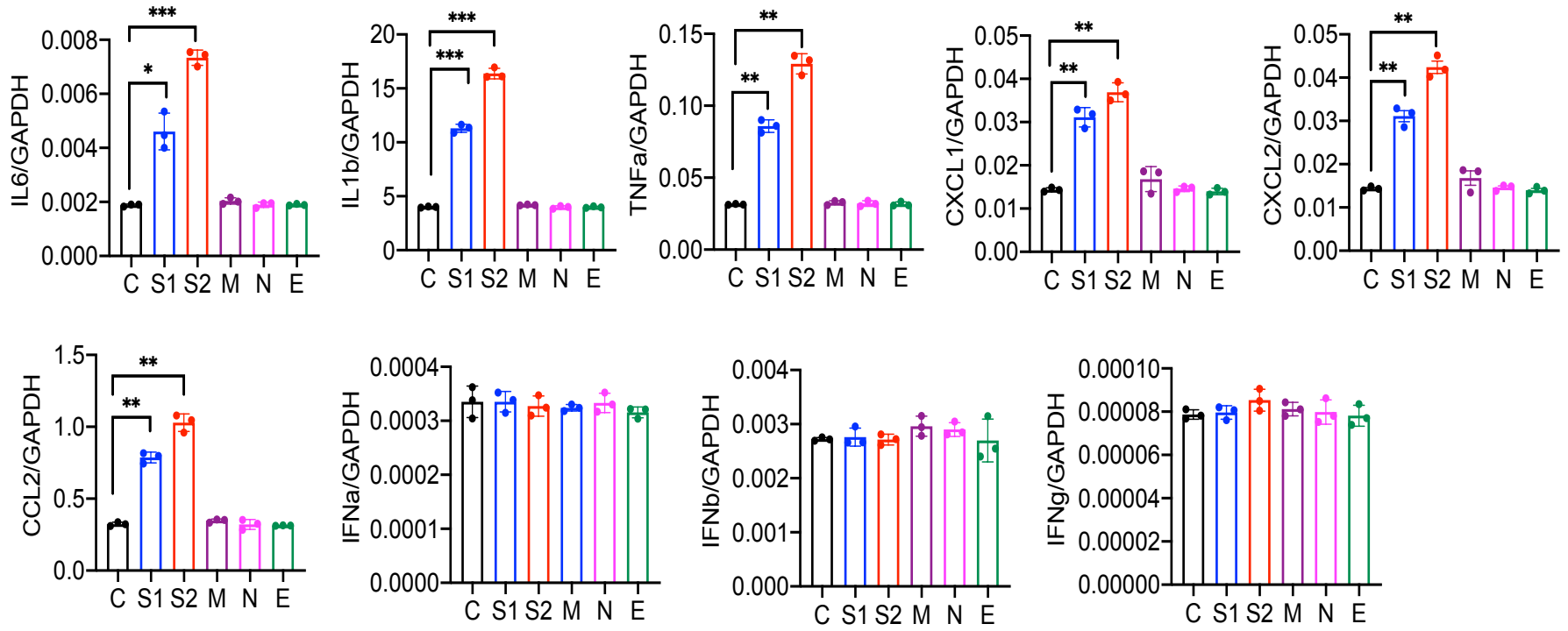

B
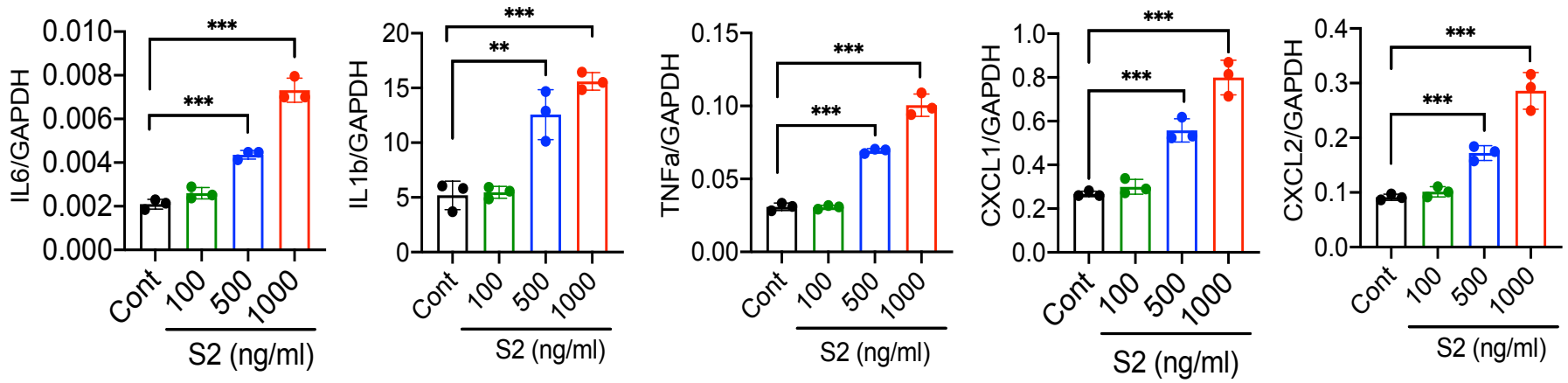

C
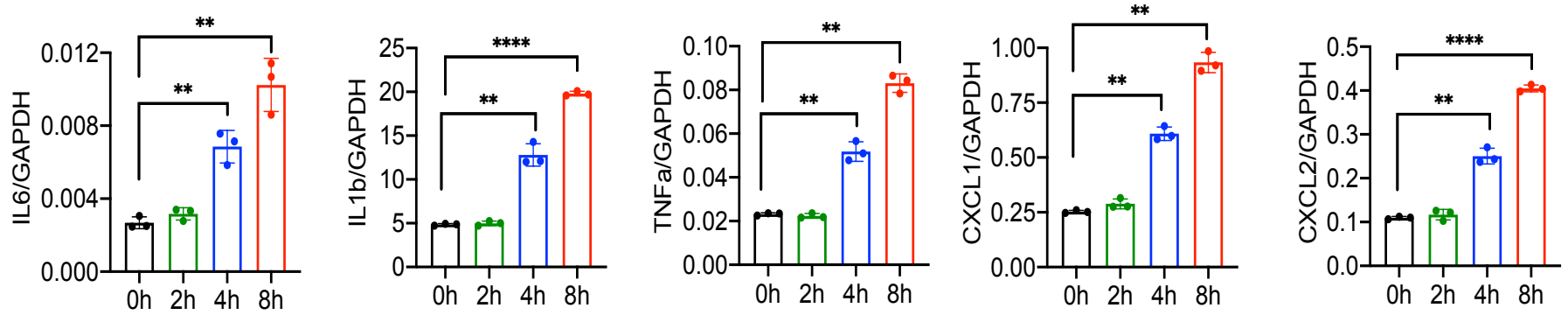

D Human PBMC
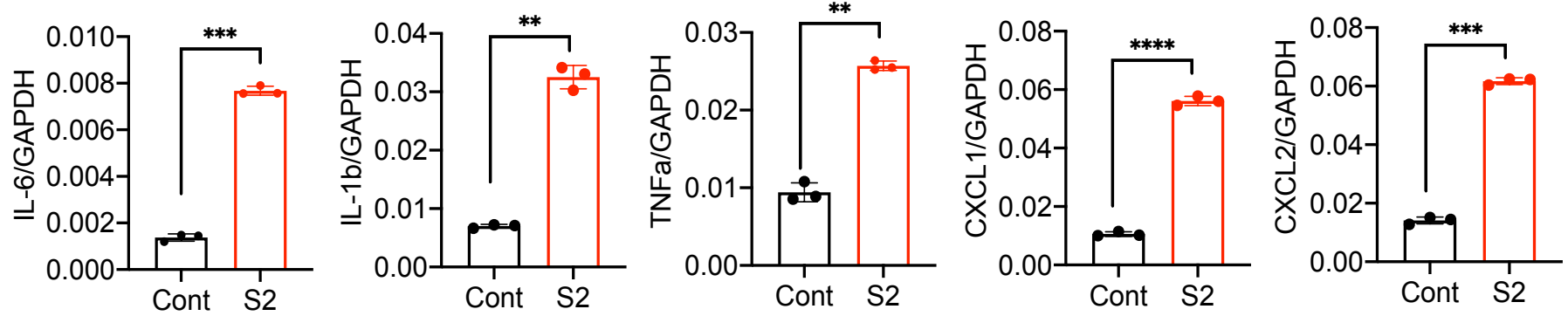
Figure 2

\section{A A549 cells}
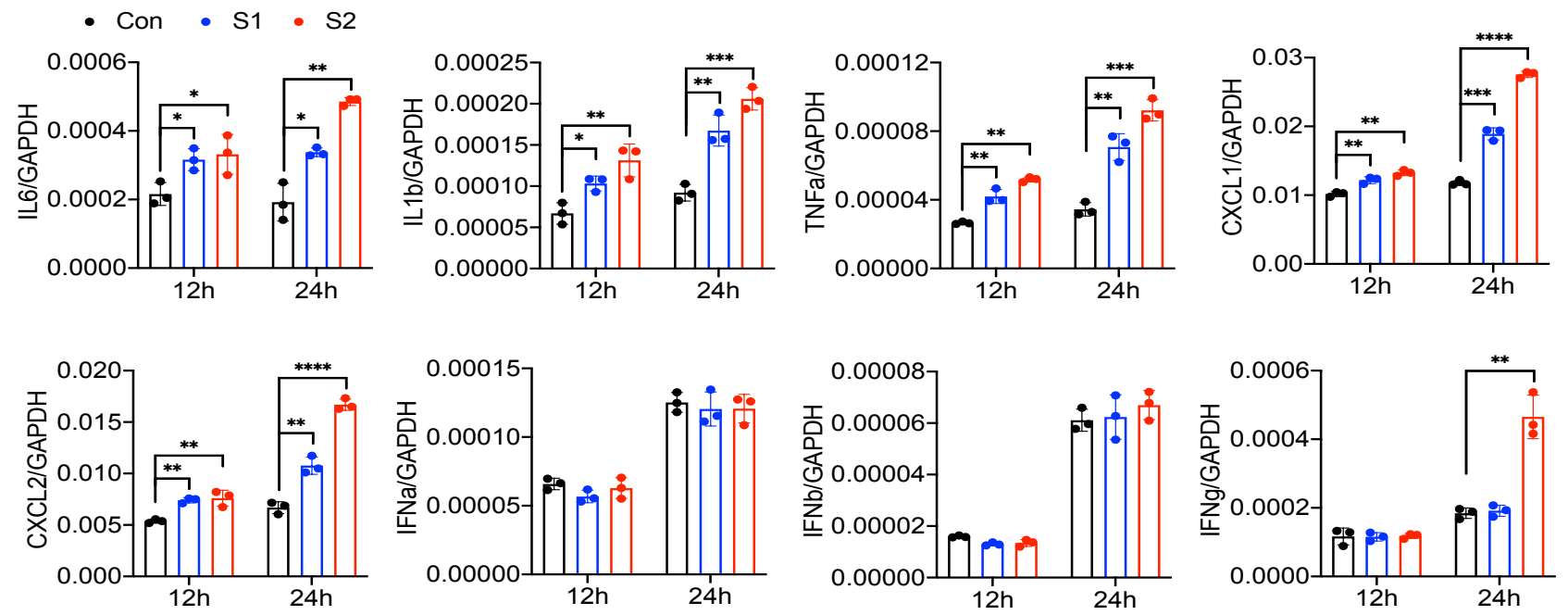

\section{B HEK293T cells}
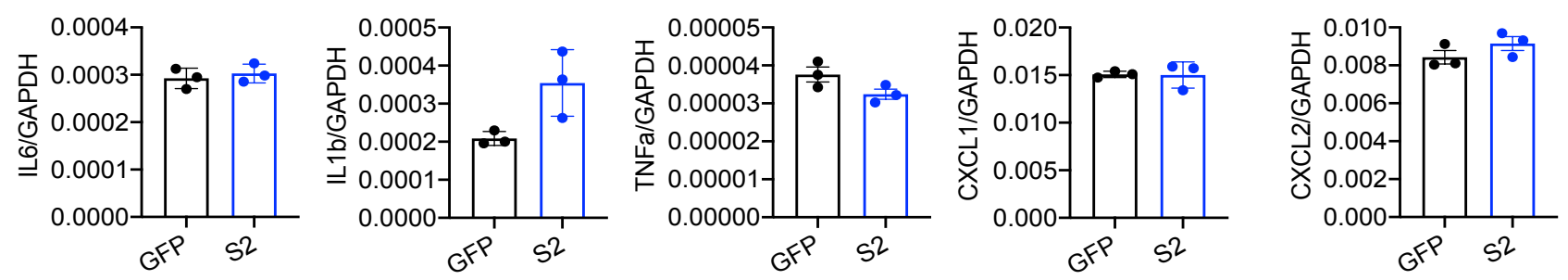

\section{A549 cells}
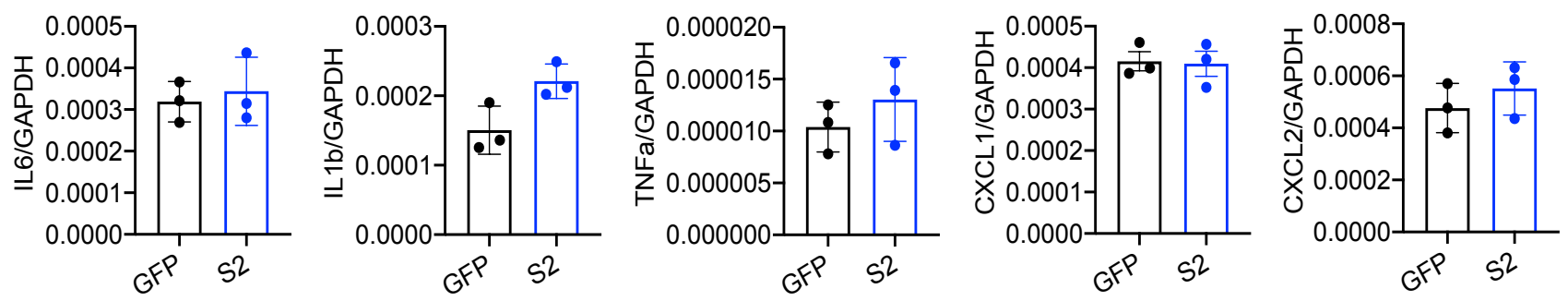
bioRxiv preprint dol: https://doi.org/10.1101/2021.03.16.435700; this version posted March 17, 2021. The copyright holder for this preprint (which was not certified by peer review) is the author/funder, who has granted bioRxiv a license to display the preprint in perpetuity. It is made available under aCC-BY-NC-ND 4.0 International license.

Figure 3

A

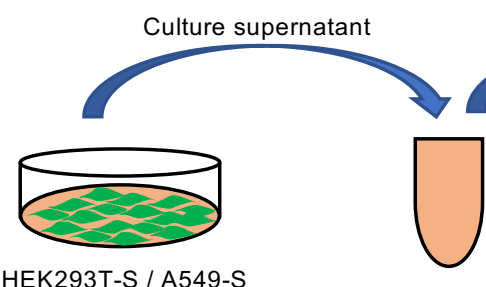

HEK293T-S / A549-S

B

THP1(HEK293T-S)
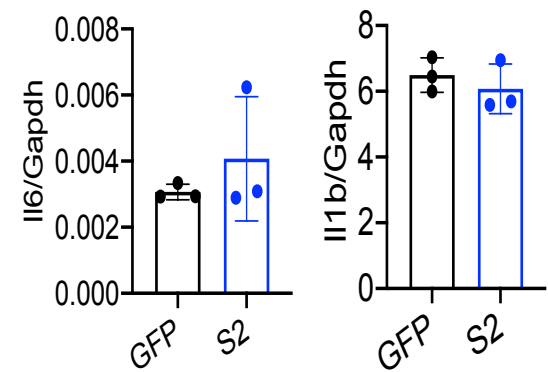

C

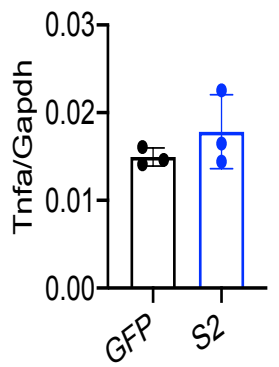

THP1(A549-S)
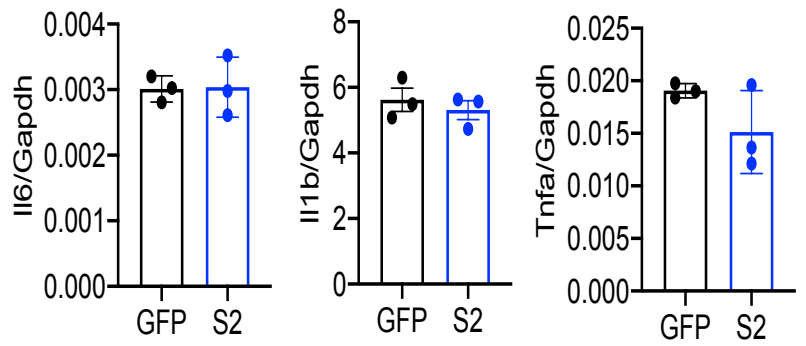

D

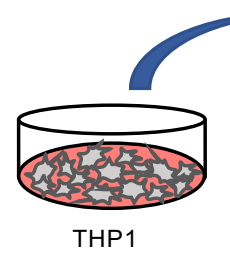

$\mathrm{E}$
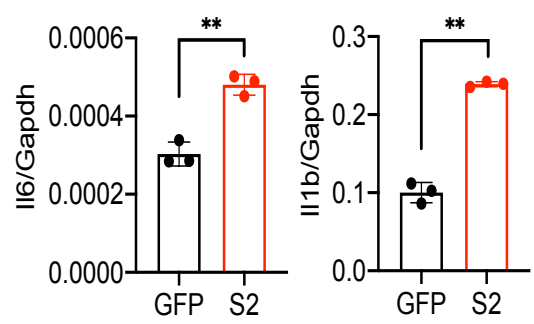

G

THP1 + HEK293T
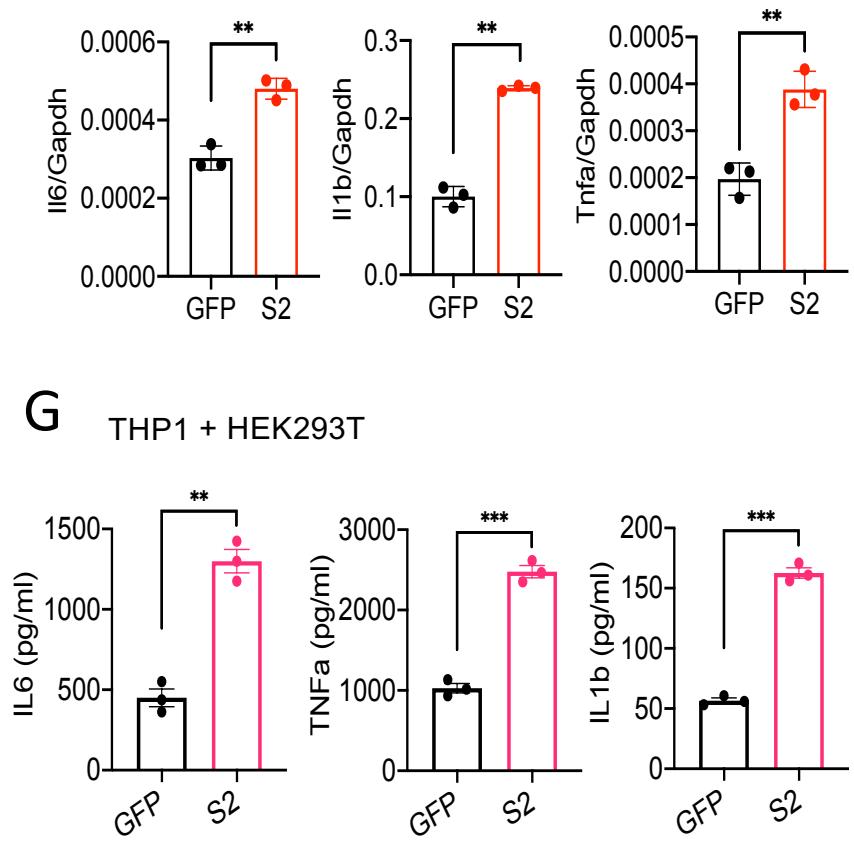

$\mathrm{H}$

F $\quad$ THP1+A549
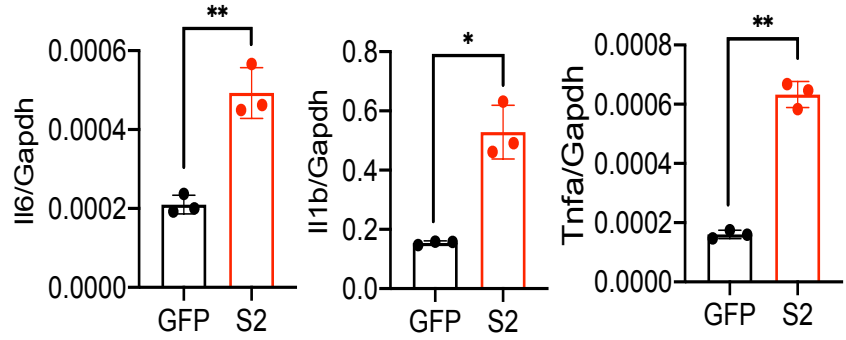

PHP + A549
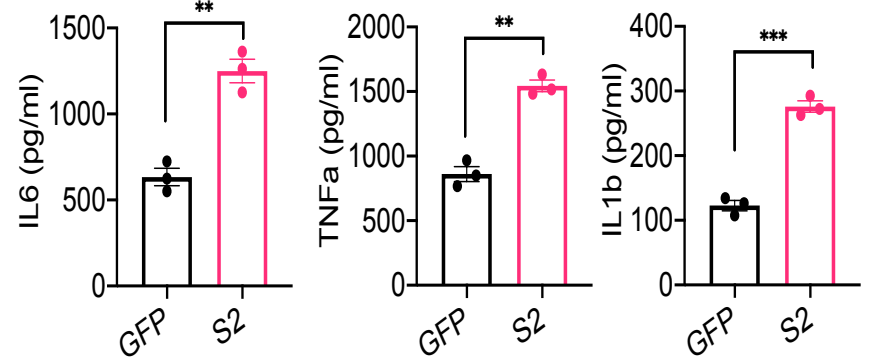
bioRxiv preprint doi: https://doi.org/10.1101/2021.03.16.435700; this version posted March 17, 2021. The copyright holder for this preprint (which was not certified by peer review) is the author/funder, who has granted bioRxiv a license to display the preprint in perpetuity. It is made available under aCC-BY-NC-ND 4.0 International license.

Figure 4
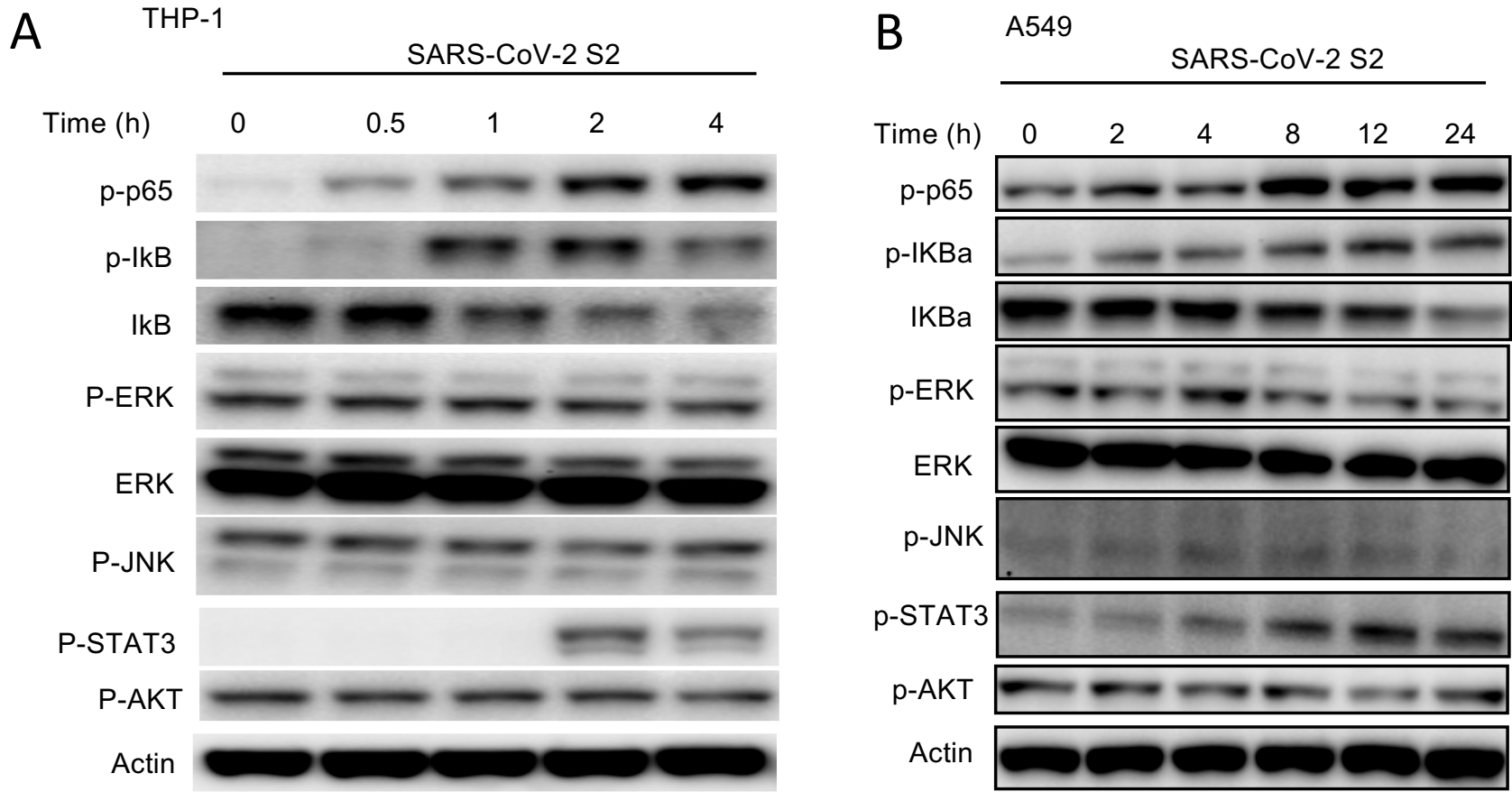

C

THP-1

Sc-514

SARS CoV-2 S2

$\begin{array}{llllllllll}\text { Time (h) } & 0 & 0.5 & 1 & 2 & 4 & 0.5 & 1 & 2 & 4\end{array}$

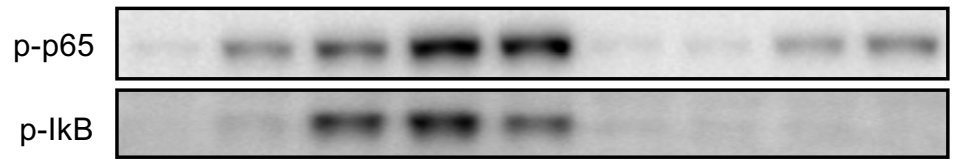

IkB

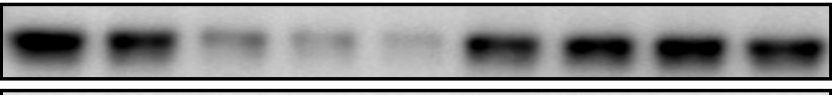

Actin

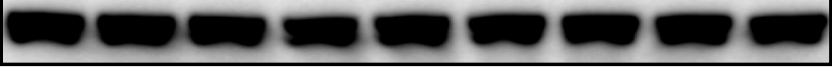

D
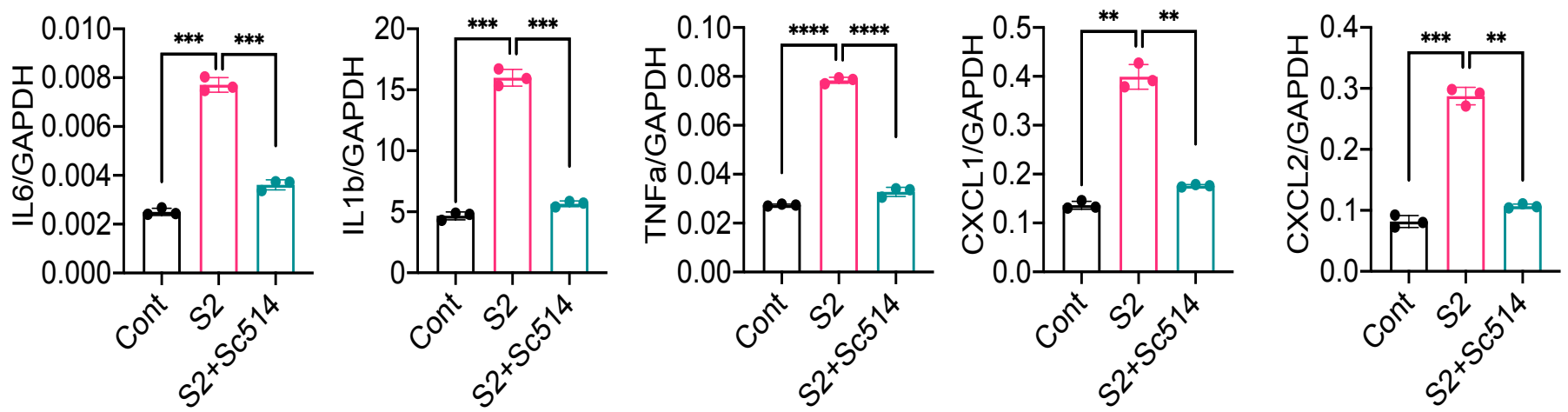


\section{A}

SARS-CoV-2 S2

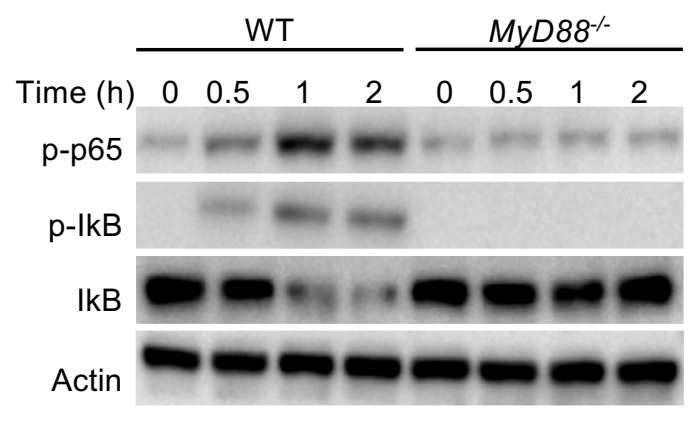

SARS-CoV-2 S2

C

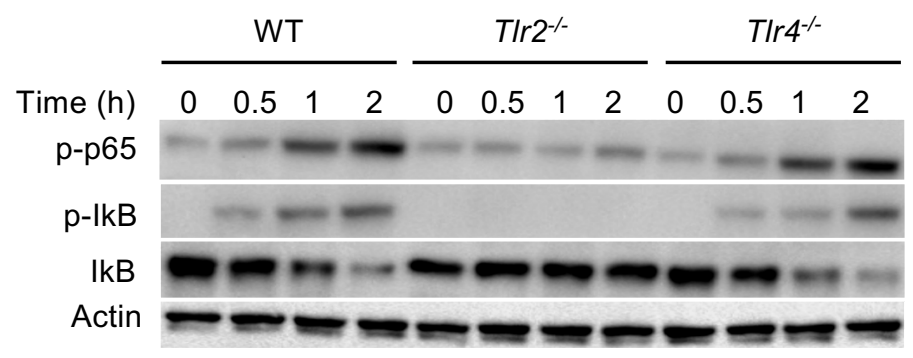

B
Figure 5
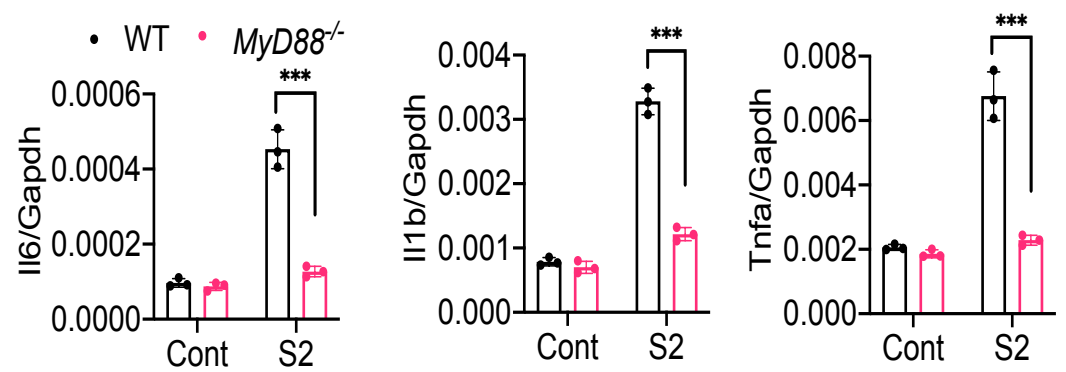

SARS-CoV-2 S1

D

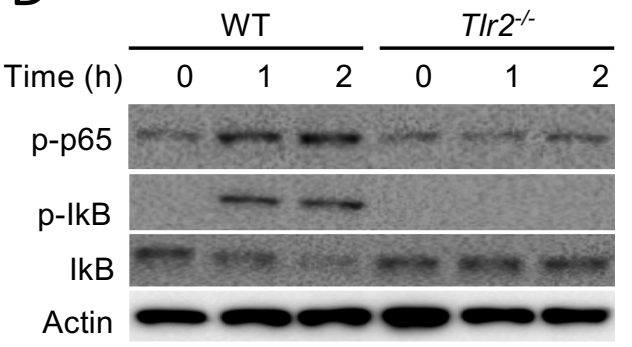

E
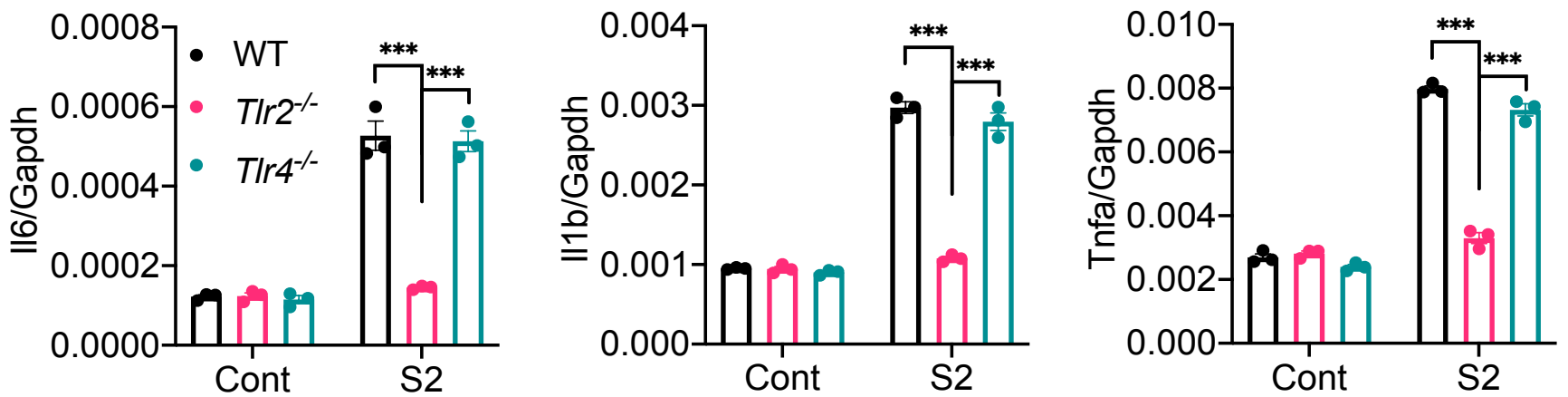

F
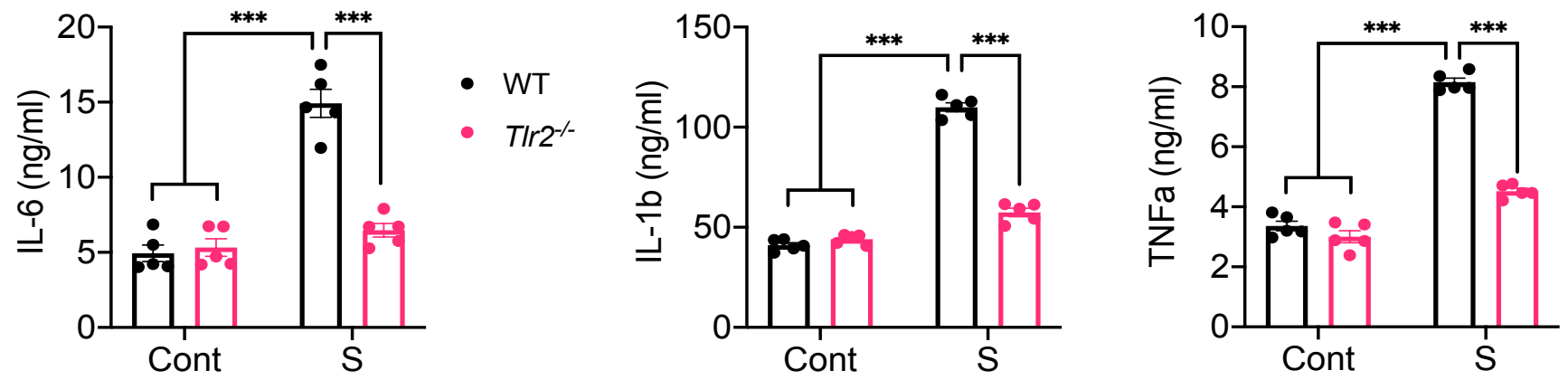